\title{
PETROLEUM PUMP PRICE SWING AND CONSUMER PRICE INDEX NEXUS IN NIGERIA: NEW EVIDENCE FROM NARDL
}

\author{
Musa Abdullahi Sakanko* \\ Department of Economics, University of Jos, Nigeria \\ E-mail: sakanko2015@gmail.com

\section{Gabriel Attah Adejor} \\ Department of Economics, University of Jos, Nigeria \\ E-mail: adejorgabriel@gmail.com \\ Sesan Oluseyi Adeniji \\ Department of Economics, University of Abuja, Nigeria \\ E-mail: adenijisesan55@gmail.com
}

\section{(Received: January 2021; Accepted: February 2021; Published: May 2021)}

\begin{abstract}
The study analyses the role of the petroleum pump price on the consumer price index in Nigeria, using the Nonlinear Autoregressive distributive lag method was used to estimate the time-series data, spanning from 1980 to 2020 . The study reveals a long-run equilibrium was found between the consumer price index and petroleum pump price measures. The empirical results obtained revealed an asymmetric relationship between the petroleum pump price and the consumer price index in Nigeria. The study recommended that the policymakers should transparently commit resources into rehabilitation and maintenance of domestic refineries to enhance their functionality and as well reduce importation cost to curtail frequent petroleum pump price adjustment that spiral domestic inflation.
\end{abstract}

Keywords: Consumer price index, NARDL, Petroleum pump price

JEL Classification: E31, C32, P43

\section{Introduction}

Globally, empirical literature (Gelos and Ustyugova, 2017) have established that oil price influences the general price level in an economy. A rise or fall in oil prices is directly related to the rate of inflation. This is because oil is a major input of

*Corresponding author: Musa Abdullahi Sakanko.E-mail: sakanko2015@gmail.com

Copyright $(0) 2021$ The Author(s). Published by VGWU Press

This is an Open Access article distributed under the terms of the Creative Commons BY 4.0 license (Creative Commons - Attribution 4.0 International - CC BY 4.0) which permits unrestricted use, distribution, and reproduction in any medium, provided the original author and source are credited.

64 scienda Studia Universitatis "Vasile Goldis" Arad. Economics Series Vol 31 Issue 2/2021 ISSN: 1584-2339; (online) ISSN: $2285-3065$ 
Sakanko, M.A., Adejor, G.A., Adeniji, S.O., (2021)

Petroleum pump price swing and consumer price index Nexus in Nigeria: new evidence from NARDL

production in the economy. Oil is used in virtually all sectors of the economy like transportation services, industrial sector, manufacturing services, domestically for cooking and generating electricity in small plants or homes, especially in developing countries where power supply is epileptic, as well as in the agricultural sector. Thus, if the intermediate costs of input rise, the cost of the output should be expected to rise too. For a micro hypothetical example, if the price of oil increases, then it will cost producers or manufacturers more to produce, and they will then transfer or pass on some or all of this cost or burden to the consumer, which raises prices and thus inflation.

As a result of the dominant role of swing in oil prices and the general price level in an economy, this study revisits the debate between oil prices and the inflation rate for the case of Nigeria. However, the approach which allows segregation was adopted to obtain the effect of first, an increase, and secondly the decrease in oil pump prices on the inflation rate. Several studies (Bobai, 2012; Sek, Teo \& Wong, 2015; Apere, 2017; Malik, Ajmal \& Zahid, 2017) revealed that there is a linear relationship between oil price fluctuation and consumer price index. Nevertheless, some recent empirical works such as (Bala \& Chin, 2018; Davari \& Kamalian, 2018) found asymmetric relationships between oil prices and inflation. However, Mukhtarov, Mammadov \& Ahmadov, (2019) argued that the variation in the sign and significance of this relationship depends on whether countries are oil exporters or importers. In the case of countries that import petroleum as raw material, oil price fluctuations do not only change their production costs, but the level of goods and services produced, and consequently, affect major macroeconomic variables such as inflation and unemployment. The case of exporting countries is relatively different in that changes in oil prices influence both supply and demand shocks. This is because in episodes of high oil prices manufacturing companies cut down production due to high production cost and the opposite is the case when the price is low but the price level does not reduce immediately as suppliers maintain the high price in sticky-price conditions.

One of the greatest problems facing the Nigerian economy today is frequent petroleum pump price adjustment which is persistently a complex economic and social problem. Petroleum pump price management has become a serious problem in the Nigerian economy and at the same time, the inability of the government to provide a lasting solution arouses a conviction that often petroleum pump price adjustment is inevitable pessimism that government has no power to stabilize the trend to an end. And it upward fluctuations cause inflation, since the country is an oil-dependent economy, increases in the prices of these products have a chain effect on the prices of other goods and services in the economy and if this is not addressed within the shortest period it might bear out to also increase unemployment, poverty and destitute, crime, robbery, crises, domestic violence, 
Sakanko, M.A., Adejor, G.A., Adeniji, S.O., (2021)

Petroleum pump price swing and consumer price index Nexus in Nigeria: new evidence from NARDL

divorce, and demand for new minimum wage. However, some scholars like Ibrahim (2015); Orlu, (2017) had argued that domestic petroleum pump price adjustment does not have a significant effect on inflation, rather change in international oil prices does. For instance, when the costs of domestic petroleum importation increase, domestic companies will increase refined oil prices to maintain a profit. This will then push upward several costs of production which include the cost of living, consumer price index, and many others because industries take in this refined oil as input and raw materials. The same thing happens when otherwise occurs.

Against this frame of reference, this study carries out an empirical examination of the following questions: What role have petroleum pump price movements played in shaping the domestic inflation rate in Nigeria since the 1980s? Has the impact of the domestic petroleum pump price adjustment changed over time? If so, which factors have accounted for this variation?

The main objective of this study is to investigate the asymmetric relationship between the consumer price index and the petroleum pump price in Nigeria. This idea was articulated because previous studies that attempted to investigate this relationship obtained mixed results; some found a linear relationship (Apere, 2017; Malik, Ajmal \& Zahid, 2017; Mukhtarov, Mammadov \& Ahmadov, 2019) while others (Choi, Furceri, Loungani, Mishra, \& Poplawski-Ribeiro, 2017; Bala \& Chin, 2018; Davari \& Kamalian, 2018) discovered nonlinear relationship. However, those studies that obtained nonlinear relationships were conducted in advanced economies, and the few attempts in Nigeria measure the effect of international oil prices/crude price on inflation rate/economic growth. More so, the responses of the macroeconomic variables to positive and negative shocks are not necessarily the same or equal, especially in the case of the consumer price index and petroleum pump price in a less developed country like Nigeria. The study checks whether such asymmetry holds or not in Nigeria.

Explicitly, the choice for the utilization of the Non-linear Autoregressive Distributed Lag (NARDL) approach of Shin, Yu, \& Greenwood-Nimmo (2014) was to examine whether the consumer price index responds asymmetrically to change or adjustment in petroleum pump prices both in the short-run and long-run in Nigeria. First, many developing countries adopt policies to limit increasing pump prices effect of petroleum on the general price level without understanding the association between them which failed to yield the desired outcome. Therefore, this study is determined to identify the kind of association (increasing/decreasing). Secondly, one of the objectives of monetary policy is price stability because high or too low inflation can be detrimental to economic growth. Therefore, the Central Bank of Nigeria must understand the kind of relationship between petroleum pump prices and inflation (Varghese, 2016), especially in a country like Nigeria that

66 sciendo Studia Universitatis "Vasile Goldis" Arad. Economics Series Vol 31 Issue 2/2021

ISSN: 1584-2339; (online) ISSN: $2285-3065$

Web: publicatii.uvvg.ro/index.php/studiaeconomia. Pages 64-79 
Sakanko, M.A., Adejor, G.A., Adeniji, S.O., (2021)

Petroleum pump price swing and consumer price index Nexus in Nigeria: new evidence from NARDL

depends on oil revenue. The inability of a proper understanding of this mechanism might lead to an ineffective monetary policy option to address the instability of the price.

The findings from the empirical estimation of the ARDL bounds test estimation reveals no long-run association between petroleum pump price and consumer price index in Nigeria. This finding corresponds with the work of Muhammad and Mansur (2018). However, the NARDL finding shows not only the long-run association but asymmetric effect. These results obtained highlighted the paramount necessity of modeling the nonlinear relationship so that the asymmetric petroleum pump price adjustments can be captured and hence suggest to serious policymakers, the appropriate dynamic policy mix to adopt in fight the rising consumer price index.

The study is structured after the introduction to include literature reviews in Section 2, Section 3 provides the methodology. Section 4 provides evidence from the discussion of results, and Section 5 provides a conclusion, recommendations, and limitation for further studies

\section{Literature review}

This section does not aim to provide a thoroughly conceptual literature review on petroleum pump prices and inflation, rather it summarizes the concepts, overview of petroleum pump price and inflation rate, the theoretical framework that guides the study, and previous work that focuses on assessing the effect of oil prices on inflation. Besides, a large number of studies have analyzed the fundamental factors elucidating the consequences of the effects of oil price shocks on inflation, though, the results are a mix.

Petroleum product is mostly used in generators and vehicles to power internal engine combustion to enhance performance and is mostly used as fuel for light road vehicles and gasoline for cooking, powering heavy vehicles and machines in the factories for production, etc (Orlu, 2017). Petroleum pump prices are the amounts charged per liter of petroleum products such as premium motor spirit (PMS), gasoline (AGO), and kerosene (DPK) while the Consumer price index or inflation is the persistent increase in the general price level of goods and services in an economy. These price increases could result from an increase in demand for goods and services due to shortages in the supply of production or an increase in input price used as an intermediate to produced goods and services. In some texts, input price is known as cost-push inflation. Inflation occurs as a result of an increase in the factor of production due to either government policy or labor action. 
In 1976 Nigeria's premium motor spirit (PMS) pump price was 9Kobo (K) and adjusted to $15.37 \mathrm{~K}$ in 1978 per liter, while the inflation rate fell from $24 \%$ to $21.7 \%$. Similarly, in the '80s the PMS pump price was adjusted four times, Gasoline (AGO) and Kerosene (DPK) shared the same eight times between 1982 and 1989. PMS pump price was increased from $20 \mathrm{~K}$ in 1982 to $39.5 \mathrm{~K}$ in $1986,42 \mathrm{~K}$ in 1988 , and $60 \mathrm{~K}$ in 1989 per liter; AGO from $12 \mathrm{~K}$ to $40 \mathrm{~K}, 48 \mathrm{~K}$ and $50 \mathrm{~K}$; and DPK from $13 \mathrm{~K}$ to $36 \mathrm{~K}, 31 \mathrm{~K}$, and $40 \mathrm{~K}$ respectively while inflation decreased from $7.7 \%$ to $5.7 \%$ in 1982 and 1986 , rose to one time higher $54.5 \%$ and $50.5 \%$ in 1988 and 1989 respectively (World Bank, 1999).

Furthermore, between 1990 and 1999 PMS pump price was adjusted nine times which rose the price from $63 \mathrm{~K}$ in 1990 to 20 Naira (N) in 1999, AGO from $\$ 1$ to $\$ 19$, and DPK from $40 \mathrm{~K}$ to $\$ 17.4$ per liter respectively. These adjustments increased the consumer price index from $7.4 \%$ in 1990 to $57.2 \%$ in 1993, 1994, and $72.8 \%$ in 1995 respectively. Although the figure dropped to $6.6 \%$ in 1999. Likewise, in the year 2000 PMS, AGO, and DPK pump price per liter were shelved up from $\$ 22$, $\$ 21$, and $\$ 17.5$ to $\$ 65, \$ 60$, and $\$ 50$ in 2005 , $\$ 97, \$ 100$, and $\$ 75$ in 2012, $\$ 145, \$ 230$, and $\$ 200$ in 2016 and $\$ 150, N 280$ and $\$ 335.54$ in 2020 respectively. These rose general price levels from $6.9 \%$ in 2000 to $18.9 \%$ in 2001 , declined to $12 \%$ in 2012 , raised to $15.7 \%$, and $16.5 \%$ in 2016 and 2017 , and reduced to $12.1 \%$ in 2018 respectively. Currently, Nigeria's inflation rate steps up from $11.6 \%$ in 2019 to $13.3 \%$ as of August 2020. This was due to the complete removal of subsidies which lead to a rise in pump price from $\$ 132$ to an average of $\$ 151.56$ to $\$ 160$ per liter (World Bank, 2019). However, the inconsistency can be attributed to corruption, demand, and supply inequality, none functional refineries, maintenance, and rehabilitation problem, high importation cost, low capacity utilization, and political change.

Inline the correlation established above, the cost-push theory of inflation was adopted as the theoretical framework in the context of this study. The theory was found on the assumption that rising oil prices, increase energy price, devaluation of the currency, increase in value-added tax (VAT), poor harvest, subsidies removal, and increase in nominal wages might lead to cost-push inflation. This signifies that an increase in petroleum pump prices can be argued to cause appreciating the consumer price index in Nigeria. This is because petroleum product enjoys inelastic demand such that an increase in the prices will lead to inflation.

Several empirical studies confirmed this correlation using different estimation tools. Among these are Ibrahim (2015); Choi et al, (2017); Bala \& Chin, (2018); Davari \& Kamalian, (2018); Muhammad \& Mansur, (2018). They employed Nonlinear Autoregressive Distributive Lagged Model and obtained that increase in

68 sciendo Studia Universitatis "Vasile Goldis" Arad. Economics Series Vol 31 Issue 2/2021 ISSN: 1584-2339; (online) ISSN: $2285-3065$

Web: publicatii.uvvg.ro/index.php/studiaeconomia. Pages 64-79 
Sakanko, M.A., Adejor, G.A., Adeniji, S.O., (2021)

Petroleum pump price swing and consumer price index Nexus in Nigeria: new evidence from NARDL

oil price has an increasing effect on inflation. In other words, an asymmetric relationship exists between oil prices and the consumer price index. Also, Gelos and Ustyugova (2017) found that high fuel price is the determining factor of increasing domestic inflation using data from both advanced and developing economies for the period 2000 to 2010. Ozdemir and Akgul (2015) employed Markov switching vector autoregressive (MS-VAR) to investigate inflationary effects of oil prices and domestic gasoline prices in Turkey and found that increase in gasoline price is more important for consumer price inflation than crude oil price shocks and there is the presence of a pass-through effect from oil price and gasoline price to core inflation. Mukhtarov, Mammadov, and Ahmadov, (2019) used Vector Error Correction Mechanism to study the effect of oil price on inflation in Azerbaijan and the result obtained reveals that inflation is observed during the periods of both high and low oil prices. Therefore, oil price fluctuation has an increase and decrease the effect on inflation. In Sek, Teo, and Wong (2015) comparative study of the effect of oil price changes on inflation, they discovered that oil price change has a direct effect on inflation in low oil dependency countries but indirect on the high oil dependency countries.

In Nigeria, Eregha, Mesagan, and Olawale (2015) examined the petroleum price and inflation dynamic using the Autoregressive Distributive Lagged model and found that the prices of PMS and AGO exert a positive effect on inflation in Nigeria. Bobai (2012) employed the Error Correction Mechanism (ECM) to examined the relationship between petroleum prices and inflation in Nigeria and found a positive relationship between PMS, AGO, and inflation. Okwanya, Moses, and Pristine (2015) investigated the impact of Petroleum Subsidy on the Consumer Price Index in Nigeria using the Error Correction Mechanism and found that changes in the fuel price have a short-run positive impact on the consumer price index. Contrary Apere (2017) adopted the Vector Autoregressive model and discovered a negative relationship between inflation and oil price fluctuation in Nigeria.

\section{Methodology}

This study utilized time-series data spanning from 1980 - 2020, obtained from the World Bank Indicators (2020). The variables were premium motor spirit (PMS), gasoline (GAS), and kerosene (DPK) measured based on the pump price per liter captured as independent variables, and consumer price index or inflation is the dependent variable. Premium motor spirit and gasoline are internal combustion engines used by vehicles and generators to enhances engine used by vehicles and generator to enhance engine performance. Kerosene is a combustible hydrocarbon liquid used for cooking and lamps. Inflation is the sustainable increase in the general price level of goods and services. 
The method of data analysis used is the Nonlinear Autoregressive Distributive Lagged (NARDL) technique. This quantitative approach is informed by its uniqueness in providing both increasing and decreasing (asymmetric) effect of the independent variable(s) on the dependent variable both in the short-run and longrun. It also reveals which of the dynamics (positive and negative) have more or larger impact on the explained variable for proper targeting policy. The autoregressive Distributive Lagged (ARDL) technique was also adopted to test whether linear co-integration exists among the twin variables to validate the findings of Muhammad and Mansur, (2018) which shows no association between the petroleum pump price and inflation. Based on the theoretical framework adopted, the econometric model for this study is established as:

$C P I=\alpha+\delta P P P+\omega i$

Where: $C P I$ is the consumer price index, $\alpha$ is the constant, $\delta$ denote the slope, $P P P$ is petroleum pump price $i$ represent exogenous determinants. The model shows a functional relationship between inflation and petroleum pump prices through cost-push effect analysis.

Following the theoretical model in equation 1, the petroleum pump price was classified into three: premium motor spirit, gasoline, and kerosene identify as determinants of consumer price index in this study. The functional specification of the model given as:

$\mathrm{CPI}=\mathrm{F}(\mathrm{PMS}, \mathrm{AGO}, \mathrm{DPK})$

Where: CPI denotes consumer price index, PMS is the premium motor spirit, AGO represents the gasoline pump price per liter and $D P K$ connotes the kerosene pump price per liter. Equation 2 demonstrates the functional relationship between the consumer price index and the determining variables used. Equation 3 was considered for the estimation of the ARDL model. Where $\beta$ 's are the parameters estimated, PMS, AGO, and DPK are regressors coefficients, $\mu$ is the error term and $t$ range from one to infinity $1,2,3 \ldots \ldots$.

CPIt $=\alpha+\beta_{1}$ PMS $_{t}+\beta_{2} \mathrm{AGO}_{\mathrm{t}}+\beta_{3} \mathrm{DPK}_{\mathrm{t}}+\mu_{\mathrm{t}}$

To achieve the objective of this study, a recent Nonlinear Autoregressive Distributive lag model was developed by Shin, $\mathrm{Yu}$, and Greenwood-Nimmo, (2014); and Pesaran, Shin, and Smith, (2001) conventional Autoregressive Distributive Lag model were adopted. The ARDL was used to validate the work of Muhammad and Mansur, (2018) of no long-run relationship between petroleum oil prices and inflation. They assumed that many studies find an insignificant relationship between economic variables due to assuming a linear relationship.

70 sciendo Studia Universitatis "Vasile Goldis" Arad. Economics Series Vol 31 Issue 2/2021

ISSN: 1584-2339; (online) ISSN: 2285 - 3065

Web: publicatii.uvvg.ro/index.php/studiaeconomia. Pages 64-79 
Sakanko, M.A., Adejor, G.A., Adeniji, S.O., (2021)

Petroleum pump price swing and consumer price index Nexus in Nigeria: new evidence from NARDL

The Nonlinear Autoregressive Distributive Lag model is specified as:

CPIt $=\alpha+\beta_{1}{ }^{+} \mathrm{PMS}_{\mathrm{tL}}+\beta_{2} \mathrm{PMS}_{\mathrm{tL}}+\beta_{3}{ }^{+} \mathrm{AGO}_{\mathrm{tL}}+\beta_{4}{ }^{-} \mathrm{AGO}_{\mathrm{tL}}+\beta_{5}{ }^{+} \mathrm{DPK}_{\mathrm{tL}}+\beta_{6} \mathrm{DPK}_{\mathrm{tL}}+$ $\mu_{\mathrm{t}}$

Equation 4 shows the long-run model for estimating the Nonlinear Autoregressive Distributive Lagged model. The model has two components: Positive and negative $\left({ }^{+}-\right)$. Where $\mathrm{PMS}_{\mathrm{tL}}$ is the long-run premium motor spirit variable, $\mathrm{AGO}_{\mathrm{tL}}$ is the long-run gasoline variable, $\mathrm{DPK}_{\mathrm{tL}}$ indicates long-run kerosene variable, $\mathrm{L}$ represents long-run symbolic, $\beta^{+}$, and $\beta^{-}$are the long-run parameters and respective coefficients. Equation 5 describes the short-run estimation.

CPIt $=\alpha+\beta_{1}{ }^{+} \mathrm{PMS}_{\mathrm{tS}}+\beta_{2}{ }^{-} \mathrm{PMS}_{\mathrm{tS}}+\beta_{3}{ }^{+} \mathrm{AGO}_{\mathrm{tS}}+\beta_{4}{ }^{-} \mathrm{AGO}_{\mathrm{tS}}+\beta_{5}{ }^{+} \mathrm{DPK}_{\mathrm{tS}}+\beta_{6}{ }^{-} \mathrm{DPK}_{\mathrm{tS}}+$ $\mathrm{ECM}_{\mathrm{t}-1}$

Where $\mathrm{PMS}_{\mathrm{tS}}$ illustrates the short-run premium motor spirit variable, $\mathrm{AGO}_{\mathrm{tS}}$ depicts the short-run gasoline variable, $\mathrm{DPK}_{\mathrm{tS}}$ suggests the short-run kerosene variable and $S$ is short-run denotation. The essence of equation 5 is to compare the short-run and long-run asymmetric effects to determine which of the partial sum has much impact on the dependent variable. The error correction mechanism demonstrates the short-run speed of adjustment to ascertain equilibrium in the long-run. It has to satisfy two conditions which are negative and statistically significant.

\section{Results and discussions}

\subsection{Descriptive Statistics}

The descriptive statistics summary of the variables used in the study is given in table 1. The act of presenting data in a meaningful way for easy interpretation refers to descriptive statistics. It presented the visualization of raw data, how it deviates from the mean, the spread of data etc.

Table 1 Descriptive Statistics

\begin{tabular}{lllll}
\hline & CPI & PMS & AGO & DPK \\
\hline Mean & 18.82165 & 46.83656 & 70.85268 & 54.50146 \\
Medium & 12.41966 & 22.40000 & 21.00000 & 17.50000 \\
Std. Dev. & 16.69503 & 50.99066 & 111.1912 & 80.71661 \\
Skewness & 1.863477 & 0.815501 & 2.610078 & 1.805519 \\
Kurtosis & 5.319458 & 2.396591 & 11.35044 & 5.546492 \\
Jarque-Bera & 32.91971 & 5.166466 & 165.6738 & 33.35386 \\
Probability & 0.000000 & 0.075529 & 0.000000 & 0.000000 \\
Observation & 41 & 41 & 41 & 41 \\
\hline
\end{tabular}

Source: Authors' Computation (2020) 
Table 1 reveals that the mean values and deviations from the mean scores for CPI, PMS, AGO, and DPK within the sample period are approximately 18.82(16.70), 46.84(50.99), 70.85(111.19), and 54.50(80.72) respectively. The AGO recorded the highest deviation. Similarly, the Skewness symbolizes positive, meaning that all the data spread from the right-hand side of the normal curve, and the Jarque-Bera test for normality, prevails that data are normally distributed.

\subsection{Empirical Results}

The study, first of all, tested the individual properties of the time-series data to ascertain the choice of technique(s) suitable and adequate to be adopted for estimating models. Thus, the Augmented Dickey-Fuller (ADF) and Phillips-Perron (PP) for unit root tests were performed and the outcomes are related in Table 2.

Table 2 Test for Unit Root Results

\begin{tabular}{lllll}
\hline & \multicolumn{2}{c}{ Level } & \multicolumn{2}{c}{ First Difference } \\
Series & ADF & PP & ADF & PP \\
\hline CPI & $-2.446^{*}$ & $-2.886^{*}$ & $-6.403^{* * *}$ & $-12.068^{* * *}$ \\
PMS & -0.958 & -0.331 & $-5.479^{* * *}$ & $-13.524 * * *$ \\
AGO & $-3.32 * *$ & $-12.454 * * *$ & -1.146 & $-2.270^{*}$ \\
DPK & $-4.476^{* * *}$ & $-11.441^{* * *}$ & $-2.843^{*}$ & $-3.969^{* * *}$
\end{tabular}

$* * *$ significant at $1 \%$ level, $* *$ significant $5 \%$ level and * significant $10 \%$ level Source: Authors' Computation (2020)

The null hypothesis of the tests has it that a particular series has a unit root. Hence, Table 2 shows that only PMS achieved stationary after the first difference in both test techniques. Then, CPI, AGO, and DPK attend stationary at a level in both ADF and PP. Since the variables have a mixed level of integration, the Autoregressive Distributive lag (ARDL) bounds test and Nonlinear Autoregressive Distributive Lag (ARDL) Bounds test were employed to verify whether a long-run relationship exists among the variables. The results are shown in Tables 3 and 4.

Table 3 Result of the ARDL Bounds Test

\begin{tabular}{lllll}
\hline Test Statistics & Value & Significance & $\mathrm{I}(0)$ & $\mathrm{I}(1)$ \\
\hline F-statistics & 1.482 & $10 \%$ & 2.37 & 3.20 \\
$\mathrm{~K}$ & 3 & $5 \%$ & 2.79 & 3.67 \\
& & $1 \%$ & 3.65 & 4.66 \\
\hline
\end{tabular}

Note: The automatic lag selection was used to determine the maximum lag length Source: Authors' Computation (2020) 
Sakanko, M.A., Adejor, G.A., Adeniji, S.O., (2021)

Petroleum pump price swing and consumer price index Nexus in Nigeria: new evidence from NARDL

Table 3 reveals no association between the variables, given the value of F-statistic (1.482) less than the upper boundary at all levels of significance; inferring that there is no co-integrating relationship between the consumer price index and the exogenous variables in the model using linear ARDL bounds test.

Table 4 Result of the NARDL Bounds Test

\begin{tabular}{lllll}
\hline Test Statistics & Value & Significance & $\mathrm{I}(0)$ & $\mathrm{I}(1)$ \\
\hline F-statistics & 3.459 & $10 \%$ & 1.99 & 2.94 \\
$\mathrm{~K}$ & 6 & $5 \%$ & 2.27 & 3.28 \\
& & $1 \%$ & 2.88 & 3.99 \\
\hline
\end{tabular}

Source: Authors' Computation (2020)

Provided that the F-statistics value (3.459) is greater than the upper boundary at $10 \%$ and $5 \%$ level of significance, the variables are said to be co-integrated, implying that the independent variables have a long-run relationship with the dependent variable. Thus, the choice of nonlinear analysis in which the use was also validated. Therefore, the estimation of the NARDL model was considered appropriate to determine the short-run and long-run asymmetric relationship between CPI and the explanatory variables in Nigeria. Table 5 presented both short-run and long-run estimates.

Table 5 Long-run NARDL Results. Dependent variable (CPI)

\begin{tabular}{lll}
\hline Variables & Coefficients & t-statistics \\
\hline PMS_POS & 14.256 & $2.903^{* *}$ \\
PMS_NEGL $_{\text {AGO_POSL }}$ & 15.024 & $2.938^{* *}$ \\
AGO_NEGL $_{\text {AGO_NEGL }}$ & -12.853 & $-2.772^{* *}$ \\
DPK_POSL & -21.646 & $-2.696^{* *}$ \\
DPK_NEGL & -3.571 & $-1.524^{* *}$ \\
\hline
\end{tabular}

Source: Authors' Computation (2020)

Table 5 presents the dynamics asymmetric results for the short-run and long-run. In the long-run, significant relationships are confirmed for the coefficients of the premium motor spirit, Gasoline, and kerosene, for both positive $\left(\mathrm{PMS}_{\mathrm{L}}^{+}, \mathrm{AGO}_{\mathrm{L}}^{+}\right.$, and $\mathrm{DPK}_{\mathrm{L}}^{+}$) and negative $\left(\mathrm{PMS}_{\mathrm{L}}^{-}, \mathrm{AGO}_{\mathrm{L}}^{-}\right.$, and $\mathrm{DPK}_{\mathrm{L}}^{-}$) components.

Table 6 Short-run NARDL Results. Dependent variable (CPI)

\begin{tabular}{lll}
\hline Variables & Coefficients & t-statistics \\
\hline PMS_POS & 0.242 & $2.690^{* *}$ \\
PMS_NEGs & 0.756 & $3.053^{* *}$ \\
AGO_POS & 0.863 & $6.085^{* * *}$ \\
\hline
\end{tabular}

$S$ sciendo Studia Universitatis "Vasile Goldis" Arad. Economics Series Vol 31 Issue 2/2021 
Sakanko, M.A., Adejor, G.A., Adeniji, S.O., (2021)

Petroleum pump price swing and consumer price index Nexus in Nigeria: new evidence from NARDL

\begin{tabular}{lll}
\hline AGO_NEGs & -34.135 & $-7.222^{* * *}$ \\
DPK_POSs & 1.613 & $5.484 * *$ \\
DPK_NEGs & 27.550 & $6.012 * * *$ \\
ECMt-1 & -1.268 & $-7.689 * * *$ \\
DW Stat. $=2.275$ & $\mathrm{R}^{2}=0.855$ & Adjusted $\mathrm{R}^{2}=0.661$ \\
\hline
\end{tabular}

Source: Authors' Computation (2020)

Similarly, table 6 shows the short-run coefficients, a significant relationship was obtained for the positive $\left(\mathrm{PMS}^{+} \mathrm{s}, \mathrm{AGO}^{+}\right.$, and $\left.\mathrm{DPK}^{+} \mathrm{s}\right)$ and negative $\left(\mathrm{PMS}_{\mathrm{s}}^{-}, \mathrm{AGO}^{-}\right.$ $\mathrm{s}$, and $\mathrm{DPK}_{\mathrm{s}}^{-}$) components of the model.

The finding also reflects that the speed of adjustment known as error correction mechanism $\left(\mathrm{ECM}_{\mathrm{t}-1}\right)$ has the required sign (negative) and statistically significant. This implies that a short-run shock was adjusted to equilibrium in the long-run with an average speed of $127 \%$ annually. The coefficient of determination $\left(\mathrm{R}^{2}\right)$ obtained indicated that the variables employed accounted for $86 \%$ variation in the explained variable and the remaining $14 \%$ not capture. This implied that the model has a good fit. The Durbin Watson statistics demonstrate the absence of autocorrelation given that the estimated value approximately is not more than 2 .

\subsection{Discussion of results and implications}

The study finds no co-integrating relationship between CPI and petroleum pump prices using the linear ARDL bounds test techniques. This was conducted to validate the previous work of (Muhammad \& Mansur, 2018); also, there is no longrun relationship between petroleum oil prices and inflation. However, the long-run relationship between the variables was obtained using the NARDL bounds test.

The positive components of PMS in the long run and short run have an appreciating effect on CPI and statistically significant, with a 1 percent increase of PMS price, leading to 14.26 and 0.24 per cents increase respectively in CPI in Nigeria. This corroborated the works of Bobai (2012); Okwanya, Moses, \& Pristine (2015); Eregha, Mesagan, \& Olawale (2015) but contrarily to Muhammad \& Mansur (2018) as reported in the literature. They found that the PMS pump price exhibits a positive effect on CPI. Still, the negative components of PMS also reveal an improving effect on CPI both in the long run and short-run. Specifically, a 1 percent decrease in PMS pump price would lead to a 15.02 and 0.76 percent increase in the CPI in Nigeria in the long run and short run respectively. This implies that even with a reduction in the PMS Price the consumer price index does not follow suit. This could be a result of the price stickiness of the Nigerian market. This is in line with the findings of Mukhtarov, Mammadov \& Ahmadov, (2019).

74 sciendo Studia Universitatis "Vasile Goldis" Arad. Economics Series Vol 31 Issue 2/2021

ISSN: 1584-2339; (online) ISSN: $2285-3065$

Web: publicatii.uvvg.ro/index.php/studiaeconomia. Pages 64-79 
Sakanko, M.A., Adejor, G.A., Adeniji, S.O., (2021)

Petroleum pump price swing and consumer price index Nexus in Nigeria: new evidence from NARDL

It was as well discovered that the long-run asymmetric impact of the PMS pump price for both the positive and negative is bigger than the short-run. This implies that the PMS pump price fluctuations exert more effects on CPI in the long run than in the short run in Nigeria within the study period.

Correspondingly, the effect of the positive and negative component of AGO on CPI is statistically significant and has a decreasing effect on CPI in the long run, with a percentage increase and decrease of AGO, resulting in an average of $12.85 \%$ and $21.65 \%$ decrease in CPI in Nigeria. The short-run components demonstrate a $0.86 \%$ increase and $34.14 \%$ decreases in CPI for a percentage increase in AGO in Nigeria. These findings revealed that the short-run negative component of AGO impact is larger than the long-run negative component. This revealed that a reduction in the pump price of gasoline has a short-run decreasing effect on the consumer's price index than in the long run. This outcome consonant with Eregha, Mesagan, \& Olawale (2015).

Nevertheless, in the long-run, the positive and negative components of DPK have a negative and statistically significant effect on CPI; a percentage increase and decrease in the DPK would respectively lead to an average of $3.57 \%$ and $51.38 \%$ reduction in CPI. This discovery showed that fluctuations in the kerosene pump price do not change the basket price of goods and services in Nigeria. This is because only a few households use kerosene in their respective homes to cook, so this makes its demand perfectly elastic. While in the short run opposite results of the long-run were obtained and statistically significant. The positive and negative components of DPK expressed a positive sign on CPI, implying that a percentage increase and decrease in the DPK will respectively bring about a $1.61 \%$ and $27.55 \%$ appreciation in CPI.

In general, the study was designed to provide an answer to these two fundamental questions. What role have petroleum pump price movements played in shaping domestic inflation since the 1980s? Has the impact of the domestic petroleum pump price adjustment changed over time? If so, which factors have accounted for this variation? It was discovered that the petroleum pump price has been playing a dynamic role in determining the consumer price index in Nigeria. And the impact of domestic petroleum pump price adjustment changes over time due to inequality between its demand and supply, inconsistent in subsidies policy, corruption, and high importation cost resulting from bad refineries conditions, etc. Therefore, policymakers must be cautious about the choice of policies to tackle inflation in the face of a high petroleum pump price. This is because a dynamic relationship like this nature needs to be accompanied by a vigorous policy mix.

After ascertaining the long-run and short-run NARDL results, there is a need to test for the underlying assumptions of the technique used which include the normal distribution of error term, serial correlation, and heteroscedasticity as well as the 
Sakanko, M.A., Adejor, G.A., Adeniji, S.O., (2021)

Petroleum pump price swing and consumer price index Nexus in Nigeria: new evidence from NARDL

stability of the estimated model to determine whether the estimation method of analysis adopted passed the classical OLS assumption, stability test and specification, established in table 7 and 8 :

Table 7 Diagnostic tests

\begin{tabular}{lll}
\hline Tests & Statistics & Prob. \\
\hline Normal distribution & Jarque-Bera & 0.000 \\
Serial correlation & Breusch-Godfrey & 0.656 \\
Heteroscedasticity & Breusch-Pagan-Godfrey & 0.999 \\
\hline
\end{tabular}

Source: Authors' Computation (2020)

The classical assumption of the OLS method employed given the probability values in table 7 shows that the error term is not normally distributed with zero mean and constant variance. So, inferential methods for linear regression are commonly established on the normality assumption for the error term. Though, a less widely understood fact amongst scholars is that, as sample sizes increase the assumption of the normality of the residuals is not desired or needed. Therefore, based on the central limit theorem, for acceptable large sample sizes, the nonnormality of residuals does not adversely affect the inferential techniques. Yet others are homoscedastic and not serial correlated. Thus, it concluded that the model passed the key assumptions test, the findings and policy suggestions of the article stand to be implemented by any relevant and concerned organizations.

Table 8 Stability tests

\begin{tabular}{lll}
\hline Tests & Statistics & Prob. \\
\hline Ramsey RESET & F-statistics & 0.984 \\
CUSUM and CUSUMQ & Stable & 0.05 \\
\hline & Source: Authors' Computation (2020)
\end{tabular}

Table 8 shows results for Ramsey RESET and CUSUM and CUSUMQ. Ramsey RESET presented with a probability value greater than $5 \%$. This implied that the model is well-specify. CUSUM and CUSUMQ are stable because the probability value is within the required region of $5 \%(0.05)$. Based on these conclusions, the policy advice from this study is reasonable.

\section{Conclusions and recommendations}

The study aimed to investigate what role have petroleum pump price movements played in shaping domestic inflation using time series data spanning from 1980 to 2020. The NARDL bounds test employed reveals that a long-run relationship exists between consumer price index and petroleum pump price measures (Premium motor spirit, gasoline, and kerosene). Findings from the empirical analysis show

76 sciendo Studia Universitatis "Vasile Goldis" Arad. Economics Series Vol 31 Issue 2/2021

ISSN: 1584-2339; (online) ISSN: $2285-3065$

Web: publicatii.uvvg.ro/index.php/studiaeconomia. Pages 64-79 
Sakanko, M.A., Adejor, G.A., Adeniji, S.O., (2021)

Petroleum pump price swing and consumer price index Nexus in Nigeria: new evidence from NARDL

that the petroleum pump price has an asymmetric effect on the consumer price index in Nigeria. On this note the followings are recommended:

The policymakers should transparently commit resources into rehabilitation and maintenance of domestic refineries to enhance functionality and as well reduce importation costs to curtail frequent petroleum pump price adjustment that spiral domestic inflation.

In the case of rising inflation in midst of petroleum pump price adjustment, policymakers should adopt a policy mix rather than a relay in one. This is because especially, the premium motor spirit was found to have back to back increasing function on the consumer price index. That is, even when the premium motor spirit adjustment is reversed downward, the inflation rate does not follow but rather continues increasing which showed downward inflexibility of prices.

Lastly, the government should man up and have the political will to lessen corruption in the oil sector. This is because most petroleum pump price adjustment was done for selfish motives.

\section{Acknowledgment}

The authors appreciate the reviewers and the Journal Studia Universitatis 'Vasile Goldis' Arad - Economics Series

\section{Funding}

This study received no funding grant from any agency, public, commercial, or profit-making organization.

\section{Author Contributions}

The authors share the research equally from introduction to literature review and methodology to allow full participation and mutual contributions.

\section{Disclosure Statement}

We declare no conflict of interest in this study

\section{References}

1. Apere, T.G.O., (2017), Crude Oil Price Fluctuation and Inflation in Nigeria, Advances in Social Sciences Research Journal, 4(3); pp. 190-200, https://doi.org/10.14738/assrj.43.2757

2. Bala, U., Chin, L., (2018), Asymmetric impacts of oil price on inflation: An empirical study of African OPEC member countries. Energies, 11(11); 3017-3033, http://dx.doi.org/10.3390/en11113017

3. Barry, W.I., (1996), Endogenous growth models, Department of Economics Penn State University Park: PA 16802 
Sakanko, M.A., Adejor, G.A., Adeniji, S.O., (2021)

Petroleum pump price swing and consumer price index Nexus in Nigeria: new evidence from NARDL

4. Bobai, F.D., (2012), An Analysis of the Relationship between Petroleum Prices and Inflation in Nigeria, International Journal of Business and Commerce, 1(12); pp. 1-7

5. Choi, S., Furceri, D., Loungani, P., Mishra, S., Poplawski-Ribeiro, M., (2017), Oil Prices and Inflation Dynamics: Evidence from Advanced and Developing Economies, International Monetary Fund, Working Paper, WP/17/196, 1-55

6. Davari, H., Kamalian, A., (2018), Oil price and inflation in Iran: Nonlinear ARDL approach, International Journal of Energy Economics and Policy, 8(3); pp. 295-300

7. Eregha, P.B., Mesagan, E.P., Olawale, O.O., (2015), Petroleum Products Prices and Inflationary Dynamics in Nigeria, Munich Personal RePEc Archive, Retrieved from https://mpra.ub.uni-muenchen.de/70251/ MPRA Paper No. 70251

8. Gelos, G., Ustyugova, Y., (2017), Inflation responses to commodity price shocks-How and why do countries differ, Journal of International Money and Finance, 72 (1); 28-47

9. Ibrahim, M.H., (2015), Oil and food prices in Malaysia: a nonlinear ARDL analysis, Agricultural and Food Economics, 3(2), 1-14

10. Malik, K.Z., Ajmal, H., Zahid, M.U., (2017), Oil price shock and its impact on the macroeconomic variables of Pakistan, International Journal of Energy Economics and Policy, 7(5); 83-92

11. Muhammad, A., Mansur, M., (2018), Is the oil price pass-through to domestic inflation Symmetric or asymmetric? New evidence from India based on NARDL, Munich Personal RePEc Archive, Retrieved from https://mpra.ub.unimuenchen.de/87569/ MPRA Paper No. 87569

12. Mukhtarov, S., Mammadov, J., Ahmadov, F., (2019), The Impact of Oil Prices on Inflation: The Case of Azerbaijan. International Journal of Energy Economics and Policy, 9(4); 97-102, https://doi.org/10.32479/ijeep.7712

13. Okwanya, I., Moses, O., Pristine, J.M., (2015), An Assessment of the impact of Petroleum Subsidy on Consumer Price Index in Nigeria, Global Journal Interdisciplinary Study, 4(1); 36-39

14. Orlu, R.N., (2017), The impact of domestic pricing of petrol on economic growth of Nigeria (1970-2013), Global journal of social sciences, 16(1); 1-8, https://dx.doi.org/10.4314/gjss.v16i1.1

15. Ozdemir, S., Akgul, I., (2015), Inflationary effects of oil prices and domestic gasoline prices: Markov-switching-VAR analysis, Petroleum Science, 12(12); 355365, https://doi.org/10.1007/s12182-015-0028-7

16. Pesaran, M.H., Shin, Y., Smith, R.J., (2001), Bounds Testing Approaches to the Analysis of Level Relationships, Journal of Applied Econometrics, 16(3); 289-326, https://doi.org/10.1002/jae.616

78 sciendo Studia Universitatis "Vasile Goldis" Arad. Economics Series Vol 31 Issue 2/2021

ISSN: 1584-2339; (online) ISSN: $2285-3065$

Web: publicatii.uvvg.ro/index.php/studiaeconomia. Pages 64-79 
Sakanko, M.A., Adejor, G.A., Adeniji, S.O., (2021)

Petroleum pump price swing and consumer price index Nexus in Nigeria: new evidence from NARDL

17. Rebelo, S., (1991), Long run policy analysis and long run growth, Journal of Political Economy, 99(3); 500-521

18. Sek, S.K., Teo, X.Q., Wong, Y.N., (2015), A Comparative Study on the Effects of Oil Price Changes on Inflation, Procedia Economics and Finance, 26 (1); 630636, https://doi.org/10.1016/S2212-5671(15)00800-X

19. Shin, Y., Yu, B., Greenwood-Nimmo, M., (2014), Modelling Asymmetric Cointegration and Dynamic Multipliers in an ARDL Framework, In: Horrace, W.C., Sickles, R.C. (eds), Festschrift in Honor of Peter Schmidt, New York: Springer Science and Business Media

20. Varghese, G., (2016), Inflationary effects of oil price shocks in Indian economy, Journal of Public Affairs, 17 (3); 1-14

21. World Bank, (1999), World development Indicators report on Nigeria, Washington DC: Author

22. World Bank, (2019), World development Indicators report on Nigeria, Washington DC: Author

23. World Bank, (2020), World development Indicators report on Nigeria, Washington DC: Author 